\title{
AKTUEL EUROPÆISK STRAFFERETSUDVIKLING - STRAFFERETLIGT SAMARBEJDE
}

AF ADJUNKT, PH.D. THOMAS ElHOLM

Until recently, the harmonisation of the substantive criminal law was one of the primary foci within the EU. That focus has now shifted to cooperation on criminal matters between police and judicial authorities. A number of framework decisions have been proposed and issued. This article describes the primary features of these decisions, beginning with the Principle of Mutual Recognition. According to this principle, decisions made by courts or judicial authorities in one EU state must be recognised and executed by all other EU states. The advantages and disadvantages of cooperation on criminal matters are examined. From a Nordic perspective, there is worry that harmonisation could increase repression. The primary Nordic concern in regard to cooperation in criminal matters is how to guarantee the protection of human rights. Yet even if human rights are ultimately guaranteed, cooperation on criminal matters raises an additional problem: Cooperation could increase the need for harmonisation and thereby increase the pressure for further repression in the Nordic countries.

\section{Indledning}

Arrangørerne af Kriminalistmødet har for denne artikel opgivet emnet "Aktuellt inom den europeiska straffrättsutvecklingen". Hvor det mest aktuelle - indtil for 2-3 år siden - var harmonisering af den materielle strafferet, så er det nu den processuelle del af de europæiske straffesystemer, der er i fokus. Det afspejles i medierne og blandt politikere, men også i kriminalisternes debatter. F.eks. handlede et sektionsmøde ved Det 36 Nordiska Juristmötet i Helsinki i 2002 netop om harmonisering af den materielle strafferet, mens konferencedeltagelse i dag afslører størst interesse for emner som arrestordre, gensidig anerkendelse af bøder, konfiskation og beviser m.v. I første del af artiklen beskrives og analyseres det strafferetlige samarbejde (afsnit 3). Samarbejdet kan dog ikke ses uafhængigt af harmoniseringsbestræbelserne, og de to fænomener sættes i relation til hinanden i sidste del af artiklen (afsnit 4).

\footnotetext{
"Title in English: Current Developments in European Criminal Law and Judicial Cooperation. Original in Danish.
} 
Skal man udlede essensen af det arbejde, som pågår, kan det efter min mening ske ved at beskrive tre - til dels sammenfaldende - krav, som i øjeblikket stilles til de europæiske landes straffesystemer, nemlig krav om gensidig anerkendelse, krav om opgivelse af princippet om dobbelt strafbarhed og krav om gensidig tillid. Jeg vil i det følgende give nogle eksempler på de tre krav og på de implikationer, som disse har for strafferetsudviklingen. Hvert aspekt kunne gøres til genstand for indgående analyser, men mest velegnet til det forestående kriminalistmøde er efter min mening et overblik over de væsentligste træk, problemer og fordele med samarbejdet.

Indledningsvis må begrebet "europæisk" kort vendes. For nærværende emne er - udover EU-reglerne - også udviklingen inden for Den Europæiske Menneskerettighedskonvention (EMRK) og Schengensamarbejdet er relevant. Det er med andre ord svært at begrænse det følgende til alene og præcis at angå EUlandene. Med dette forbehold er det dog alligevel hovedsageligt disse lande, og de forskellige EU-organer, som jeg har for $\emptyset$ je. Det er i den sammenhæng i $\emptyset \mathrm{v}$ rigt interessant, at Kommissionen flere gange i titler på retsakter bruger ordet "europæisk" frem for EU, f.eks. forslag til rammeafgørelse om en europaisk bevissikringskendelse. Ordet europæisk bruges, skønt reglerne kun er møntet på et stærkt begrænset antal europæiske lande. Måske skyldes det, at reglerne kan få gyldighed i visse ikke-EU-lande, hvis disse lande ønsker det (f.eks. Schengenlandene Norge og Island).

\section{Udviklingen i det strafferetlige samarbejde}

Udviklingen i det strafferetlige samarbejde mellem EU-landene kan (indtil videre) inddeles $i$ tre faser. I pre-unionsfasen var reglerne europæiske $\mathrm{i}$ bred forstand, dvs. ikke baseret på EU. De går en del år tilbage i tiden, f.eks. Europarådets konventioner af 1957 om udlevering af lovovertrædere og af 1959 om gensidig retshjælp i straffesager. Det er kendetegnende for disse regler, at landene i relativt vidt omfang havde mulighed for at opretholde forskellige betingelser for at yde retshjælp og udlevere, bl.a. betingelsen om dobbelt strafbarhed.

Den næste fase kan betegnes tidlig-unionsfase. Den begynder med Maastricht-traktaten og fortsætter lidt ind i Amsterdam-traktatens periode. I denne fase betjener man sig fortsat af konventioner, f.eks. de to EU-konventioner fra henholdsvis 1995 og 1996 med henblik på at supplere 1957-konventionen og lette mulighederne/procedurerne for udlevering til strafforfølgning. Der blev også vedtaget en konvention fra 2000 om gensidig retshjælp i straffesager (og en protokol om bankinformation), som skal gøre mulighederne for hjælp til bevisoptagelse m.m. lettere mellem landene. I denne fase angribes kravet om dobbelt strafbarhed, og man forsøger generelt at indskrænke mulighederne for at afslå retshjælp/udlevering. 
Den tredje fase, som vi er på vej over i nu, kunne kaldes for mellemfasen. I denne fase anvendes rammeafgørelser i stedet for konventioner. Den er herudover navnlig karakteriseret ved to ting. For det første ideen om, at alle medlemslandene umiddelbart skal anerkende de øvrige landes domme, afgørelser og kendelser. Kravet om dobbelt strafbarhed skal derved ideelt set opgives, og mulighederne for at afslå fuldbyrdelsen af andre landes afgørelser m.m. indskrænkes til et minimum. Det er et koncept, som i en vis forstand skaber det fælles EUretsrum, der er unionens målsætning (jf. området med frihed, sikkerhed og retfærdighed i traktatens artikel 2), selvom der eksisterer forskellige nationale strafferegler.

Fasen er for det andet karakteriseret ved, at den udgør en vigtig overgang, før landenes materielle strafferet er blevet helt ensrettet, før EU har fået en forfatning med nye muligheder for strafferetlig regulering, før EU har fået et egentligt, operationelt politi eller en anklagemyndighed, og ikke mindst før EU har fået en forfatning med fundamentale rettigheder for individet. Det er en vigtig fase af en række grunde, bl.a. fordi der her skabes dele af det fundament, som kommer til at udgøre fremtidens EU-strafferet.

En del af dette fundament er som nævnt princippet om gensidig anerkendelse. Oprindelsen kan føres tilbage til 1998, til det britiske formandskab og til mødet i Cardiff i 1998 (se Asp 2004), men fik sin placering som centralt princip for EU's udvikling af strafferetten under Det Europæiske Råds møde i Tammerfors i 1999. Her blev princippet udråbt til "cornerstone". Allerede ordet antyder princippets fundamentale betydning. Udnævnelsen gjaldt i $\varnothing v r i g t$ ikke bare i strafferetten, men også det civilretlige samarbejde, hvor man var først med gensidig anerkendelse, og hvorfra de strafferetlige EU-regler henter inspiration. I 1998 anmodede Rådet i øvrigt Kommissionen om et arbejdsprogram med henblik på gennemførelse af princippet om gensidig anerkendelse i straffesager. I de sidste par år har vi derefter set frugterne af disse bestræbelser.

\section{Udmøntning af princippet om gensidig anerkendelse}

\subsection{De enkelte retsakter}

Der er hidtil vedtaget to retsakter og fremsat en række forslag, som bygger på princippet om gensidig anerkendelse:

Rammeafgørelse om:

- $\quad$ arrestordre (EFT L 190/1 af 18.7.2002)

- indefrysning af formuegoder og bevismateriale (EFT L 196/45 af 2.8.2003)

Forslag til rammeafgørelse om:

- gensidig anerkendelse af bødestraffe (EFT C 278/4 af 2.10.2001) 
- gensidig anerkendelse af afgørelse om konfiskation (EFT C 184/8 af 2.8.2002)

- rettighedsfrakendelse (EFT C 223/17 af 19.9.2002)

- $\quad$ ne bis in idem (EFT C 100/24 af 26.4.2003)

- en europaisk bevissikringskendelse (KOM(2003)688 af 14.11.2003)

Rammeafgørelserne er i høj grad opbygget på samme måde (bortset fra den om rettighedsfrakendelse, der blot er en indledende foranstaltning med henblik på senere at gennemføre gensidig anerkendelse, og den om ne bis in idem, som modsat de andre ikke har til formål at styrke retshåndhævelsen, men derimod individets retsgarantier). Nogle af de væsentligste fælles træk gennemgås i det følgende.

\subsection{Falles traek}

Rammeafgørelserne giver alle udtryk for, at de bygger på princippet om gensidig anerkendelse. Det betyder principielt, at en afgørelse truffet i et land automatisk skal anerkendes og fuldbyrdes i et andet land og på samme måde, som hvis afgørelsen var truffet i dette land. Der står typisk i rammeafgørelserne, at en anmodning fra et andet land skal "anerkendes uden yderligere formaliteter".

Mulighederne for at efterprøve og afslå fuldbyrdelsen af en afgørelse truffet $i$ et andet land begrænses. Prøvelsen begrænses f.eks. ved, at der typisk blot skal oversendes en attest eller formular, hvorved bevisstyrken i en sag ikke vurderes. Prøvelsen begrænses i praksis også af, at der i nogle tilfælde gælder meget korte frister for fuldbyrdelse.

Afslagsgrundene begrænses ved, at princippet om dobbelt strafbarhed (delvist) ophæves, og ved at der opstilles udtømmende lister over afslagsgrunde. Princippet om dobbelt strafbarhed begrænses i alle rammeafgørelserne ved hjælp af en såkaldt positivliste. Hvis en afgørelse fra et andet land vedrører en forbrydelse på denne liste, og der er en strafferamme på minimum 3 år i dette andet land, så kan der ikke stilles krav om dobbelt strafbarhed. De øvrige afslagsgrunde begrænses også. Listen over gyldige afslagsgrunde i de forskellige retsakter varierer en del. Der skelnes typisk mellem obligatoriske og fakultative afslagsgrunde. I forslaget til rammeafgørelsen om bevissikringskendelser er listen meget kort og omfatter stort set blot mulighed for afslag med henvisning til forbuddet mod dobbelt strafforfølgning (ne bis in idem) eller undtagelse for personer med immunitet. Listen over afslagsgrunde i de rammeafgørelser, som er vedtaget, er typisk noget længere. I rammeafgørelsen om arrestordre omfatter listen bl.a. regler om amnesti, ne bis in idem, kriminel lavalder, tilfælde hvor fuldbyrdelseslandet forpligter sig til selv at fuldbyrde straffen, og tilfælde hvor overtrædelsen er sket helt eller delvist på fuldbyrdelseslandets territorium. 
Udover afslagsgrundene indeholder flere af rammeafgørelserne også bestemmelser om mulighed for $u d s a t t e l s e$ af den pågældende afgørelse, bl.a. i den om arrestordre, hvor udlevering kan udsættes af humanitære grunde.

Attester eller formularer synes at være en del af konceptet med gensidig anerkendelse (også på det civilretlige område). Rammeafgørelserne opstiller næsten alle en slags formulartvang. Fuldbyrdelse af en afgørelse fra et andet land kan således afslås, hvis der ikke er benyttet den formular, som rammeafgørelsen foreskriver (eller hvis formularen er mangelfuldt udfyldt). Ideen med formularerne er, at proceduren i fuldbyrdelseslandet skal kunne gå hurtigt og lettere. Det anses for en væsentlig hindring ved det strafferetlige samarbejde mellem landene, at det er besværligt og tager for lang tid.

I forbindelse med alle rammeafgørelserne har lovgiver/forslagsstiller været opmærksom på konsekvenserne for individets retssikkerhed og grundlæggende rettigheder. Der henvises konsekvent til EU-traktatens art. 6 vedrørende EU's principielle tilslutning til grundlæggende retsprincipper og EMRK. I nogle rammeafgørelser er det blot en henvisning i præamblen, i andre en selvstændig artikel. Visse rammeafgørelser henviser endvidere i præamblen til specifikke garantier eller principper, f.eks. om nødvendighed og proportionalitet af et indgreb. Forslaget vedrørende bevissikringskendelse går et skridt videre. I en særskilt artikel foreskriver det disse principper og flere andre (bl.a. forbuddet mod selvinkriminering) anvendt i forbindelse med behandling af en afgørelse fra et andet land.

\subsection{Dobbelt strafbarhed}

Kravet om dobbelt strafbarhed har været en grundlæggende forudsætning for international retshjælp og udlevering m.m., men står nu for fald. Kravet er - ifølge rammeafgørelsen om bevissikringskendelse, præamblens punkt 10 - ikke foreneligt med princippet om gensidig anerkendelse.

I forbindelse med en høringsrunde vedrørende protokollen til 2000-konventionen om retshjælp udtrykte en hel række danske myndigheder og organisationer betænkeligheder ved opgivelse af kravet om dobbelt strafbarhed, bl.a. Rigsadvokaten, Statsadvokaten for særlig økonomisk kriminalitet, Politidirektøren i København, Advokatrådet, Landsforeningen af beskikkede advokater, Den Danske Dommerforening, Foreningen af Politimestre i Danmark og Finansrådet. Betænkelighederne gik bl.a. på, at det ville være et brud på et fundamentalt princip i dansk ret, at den konkrete bestemmelse var meget vidtgående og ikke umiddelbart overskuelig, og at dansk standard for retsbeskyttelse kunne være truet. Færre synes at have haft betænkeligheder ved opgivelse af kravet om dobbelt strafbarhed i forbindelse med rammeafgørelserne om bødestraffe og konfiskation. Men 
kritikken er ikke helt forstummet. En vis svækkelse af betænkelighederne kan efter min mening skyldes to aspekter, som omtales nærmere i det følgende.

\subsection{Grader af gensidig anerkendelse}

For det første har opgivelsen af kravet om dobbelt strafbarhed forskellig rækkevidde afhængigt af, hvor mange og hvilke forbrydelser positivlisten omfatter, samt hvor mange og hvilke undtagelsesmuligheder der er i de forskellige rammeafgørelser. Som påpeget af Asp (2004), er springet fra den traditionelle retshjælp til gensidig anerkendelse ikke særlig stort, hvis anvendelsesområdet er begrænset (f.eks. til nogle få specifikke forbrydelser) og undtagelserne mange. Det karakteriserer til en vis grad de foreliggende rammeafgørelser. I så henseende er der ikke tale om nogen revolution. Det er dog værd at understrege, at der er tale om et principielt vigtigt skridt, og sandsynligvis vil anvendelsesområdet blive markant udvidet og afslagsgrundene stærkt begrænset i nærmeste fremtid.

\section{5. Ønsket om gensidig tillid}

En anden grund til, at betænkelighederne ved opgivelse af kravet om dobbelt strafbarhed synes nedtonet, kan være politisk. Der breder sig i disse år et krav om, at vi som europæere må have gensidig tillid ("mutual trust") til hinandens retssystemer. Kravet støttes på navnlig to typer af argumenter. Den ene type vedrører nødvendigheden. Gensidig tillid er nødvendig for at skabe et fælles europæisk "retsrum", nødvendig for at dette rum skal være funktionsdygtigt, og dette retsrum er endvidere nødvendigt på grund af globaliseringen og den fri bevægelighed i EU. Den anden type argument vedrører grundlaget for evt. mangel på tillid. Skepsis over for andre landes retssystemer er overdrevet, fordi vi ligner hinanden (vestlige demokratiske retsstater), fordi vi alle er bundet af Menneskerettighedskonventionen, og fordi vi alle har huller i retsbeskyttelsen, så niveauforskellen i retsbeskyttelsen ikke er så stor (om sidstnævnte se f.eks. Vestergaard 2004, s. 650).

Der kan føres lange diskussioner om rigtigheden og vægten af disse argumenter. Det vil blive for omfattende i denne sammenhæng. Lad mig blot påpege et misvisende element ved begrebet "mutual trust" eller gensidig tillid. Der er tale om et plusord, som automatisk gør sin modsætning til et minus-ord. Det er således pr. automatik negativt $i k k e$ at have gensidig tillid til hinanden, navnlig i et ægteskab som EU. Ved at anvende begrebet gensidig tillid bliver ønsket om beskyttelse af national egenart automatisk til noget negativt. Men det handler jo ikke - $\mathrm{i}$ hvert fald ikke altid - om tillid. Det handler i vidt omfang om forskellige holdninger til indretning af straffesystemer. 


\subsection{Individets retsbeskyttelse}

Det hedder i præamblen til rammeafgørelsen om bevissikringskendelser, at princippet om gensidig anerkendelse er baseret på en høj grad af tillid mellem landene, og for at styrke tilliden skal rammeafgørelsen indeholde visse retsgarantier (punkt 8). Omfattet er krav om, at fuldbyrdelsesmyndigheden skal anvende den mindst indgribende foranstaltning, at en fysisk person ikke må anmodes om at fremlægge dokumenter m.m., som kan føre til selvinkriminering, og at ransagning af lokaler ikke må påbegyndes om natten, medmindre det er absolut nødvendigt. Det er et prisværdigt fors $\emptyset \mathrm{g}$ på at styrke borgernes retsgarantier.

De $\varnothing$ vrige rammeafgørelser henviser blot til de grundlæggende rettigheder og principper, som ifølge EU-traktatens art. 6 er en del af EU-samarbejdet. Og der er vel grund til at understrege, at landenes tilslutning til EMRK faktisk sikrer en vis minimumsbeskyttelse af individet. På visse områder er det endda misvisende at kalde beskyttelsen for "minimum", fordi der er tale om en meget høj grad af beskyttelse. På den anden side er det klart, at et land på visse områder kan ønske at give en bedre beskyttelse end den, som følger af EMRK. Det kan ikke udelukkes, at princippet om gensidig anerkendelse til en vis grad vil kunne underminere en sådan forstærket beskyttelse.

\section{Harmonisering af materiel strafferet kontra strafferetligt samarbejde 4.1. Indledning}

Som Asp (2004) skriver, anses strafferetligt samarbejde mellem EU-landene undertiden som et alternativ til harmonisering af den materielle strafferet. Af gode grunde er dette næppe en retvisende anskuelsesmåde (jf. Asp, 2004). Selvom det er klart, at harmonisering og strafferetligt samarbejde er integrerede fænomener, så er det på den anden side også klart, at der på nuværende trin i EU’s udvikling kan lægges større eller mindre vægt på det ene eller det andet. I det følgende gennemgås kort nogle fordele ved strafferetligt samarbejde kontra harmonisering af materiel strafferet.

I forbindelse med de følgende afsnit har det ikke været muligt at komme uden om en analyse af Asp (2004). Det følgende er en udbygning af Asps forbilledlige analyse, der desværre i skrivende stund kun foreligger som konferencepapir (- der vil formentligt ske visse ændringer i Asps analyse inden offentliggørelse senere på året).

\subsection{Fordelene-kritisk perspektiv}

Asp (2004) nævner tre fordele. For det første er udgangspunktet for strafferetligt samarbejde et andet end for harmonisering af materiel strafferet. Internationalt strafferetligt samarbejde rummer mange muligheder for forbedringer. Området er mindre udviklet end landenes egen strafferet, og der er dermed gode muligheder for at tage små, forsigtige skridt med positiv virkning i praksis, uden at få uheldige bivirkninger med i købet. Jeg kan til en vis grad tilslutte mig Asps argument, men har tre indven- 
dinger eller tilføjelser. For det første: Selvom der er gode muligheder for at lave velafbalancerede løsninger, for så vidt angår strafferetligt samarbejde, så er problemet, at der også er mulighed for at lave ubalancerede løsninger. Det sker let i en ophedet situation, som f.eks. efter 11. september 2001 og 11. marts 2004. Asp (2004) nævner selv dette problem. For det andet: Det er ikke kun på området for strafferetligt samarbejde, at der er gode muligheder for at lave velafbalancerede løsninger. Det gælder også for så vidt angår harmonisering af materiel strafferet, f.eks. hvis man udviser en vis tilbageholdenhed og giver tid (Greve, 1995), samt hvis man lader regeldannelsen styre af grundlæggende gode principper for kriminalisering (Träskman, 2002). Også i denne sammenhæng er problemet ikke reguleringen i sig selv, men den politiske stemning, der styrer den. For det tredje: Den hidtidige harmonisering af materiel strafferet er på nogle punkter relativt betydningsløs. De mange harmoniseringstiltag har f.eks. endnu ikke betydet nogen nævneværdig harmonisering af de almindelige strafbarhedsbetingelser (tilregnelse, tilregnelighed, medvirken, fors $\emptyset \mathrm{g}$ etc.). I retsakterne nøjes man typisk med at fastslå, at forsætlig overtrædelse skal straffes (uden egentlig definition af forsæt), og at landene skal straffe medvirken (uden egentlig definition heraf). I så henseende kan harmonisering af materiel strafferet også ske ved "små skridt".

Det andet, Asp påpeger, er styrken af argumenterne for strafferetligt samarbejde. Disse er meget stærkere end for "øget repression". Som Asp skriver, er det ikke helt uden substans, når der henvises til, at fri bevægelighed af personer m.m. må modsvares af en fri bevægelighed for judicielle myndigheder. Det er naturligvis problematisk, hvis lovovertræderne kan bevæge sig frit fra stat til stat, mens myndighederne "hænger fast i statsstrukturen" (jf. også Asp, 2004). Jeg kan helt tilslutte mig denne anskuelse, men det må nok tilføjes, at selvom argumenterne for harmonisering af materiel strafferet er mindre gode, så har de faktisk haft en særdeles effektiv gennemslagskraft.

Den tredje fordel med strafferetligt samarbejde frem for harmonisering er, at det er "clear from the very beginning that the interests of the state in efficiency must be balanced against the interests and rights of the individual" (Asp, 2004). Individets retsbeskyttelse er så at sige en del af selve konceptet for strafferetligt samarbejde, mens der ikke er noget "equality of arms" princip i forbindelse med materiel strafferet (Asp, 2004). Desuden er problemerne med overkriminalisering mindre åbenlyse end problemerne ved statens magtanvendelse over for individet (Asp, 2004). Også disse betragtninger kan jeg tilslutte mig, men ikke uden visse tilføjelser. For det første: Individets retsbeskyttelse har en relativt tilbagetrukken placering i de EUretsakter, som er nævnt i denne artikel. Den fremgår i flere tilfælde blot af en generel henvisning i en præambel. Retsakter, som skal sikre indgreb over for borgerne på tværs af grænserne, er mange, men retsbeskyttelsen er hidtil henvist til "studier", f.eks. i Grønbog om Retssikkerhedsgarantier for mistænkte og tiltalte i straffesager i 
EU (KOM(2003)75 af 19.2.2003). Der er en enkelt undtagelse, nemlig rammeafg $\varnothing-$ relsen om ne bis in idem, som skal udbygge princippet om forbud mod dobbelt strafforfølgning. Det er tankevækkende, at netop dette ene forslag om individets retsgarantier har haft og fortsat har meget svært ved at blive til virkelighed. Medlemslandene $\emptyset$ nkker en lang række undtagelser til princippet. Det er altså ikke bare bekymringer vedrørende retsbeskyttelsen, der volder problemer i forbindelse med princippet om gensidig anerkendelse, men også bekymringer vedrørende muligheden for retshåndhavelse. Netop ne bis in idem havde ellers været et oplagt emne for en meget vigtig forbedring af individets retsbeskyttelse i et EU med fri bevægelighed for borgere og myndighederne.

\subsection{Problemerne}

Hermed er tre fordele ved strafferetligt samarbejde nævnt (jf. Asp 2004) og diskuteret. Lad mig kort nævne nogle problemer (jf. også Asp 2004). For det første: Princippet om gensidig anerkendelse skaber en vis afstand mellem dom/afgørelse og fuldbyrdelsen. Et berygtet eksempel vedrørte tre svenske statsborgere, som havde fåt deres formue indefrosset af de svenske myndigheder, fordi deres navne stod på EU’s terrorfinansieringsliste (bilag til EU's forordning nr. 467/2001). Denne liste var udarbejdet efter en tilsvarende liste fra FN's Taleban-sanktionskomite, hvoraf deres navne fremgik. De tre tog uformel kontakt til repræsentanterne i komiteen og med repræsentanter for de amerikanske myndigheder, som havde leveret oplysningerne, der lå til grund for optagelsen af deres navne. Selvom flertallet af medlemmerne i sanktionskomiteen udtalte sig til støtte for en ophævelse af sanktionerne over for de tre, blev deres optagelse på listen opretholdt, fordi tre stater var imod ophævelse. Først efter 9 måneder blev indefrysningen ophævet. Personerne har i mellemtiden anlagt sager ved Retten i Første Instans (der er afsagt en kendelse vedrørende anmodning om udsættelse, sag T-306/01 R, men hovedsagerne T-315/01 og T-318/01 verserer fortsat). Som Cameron (2002, s. 12) skriver, løser ophævelsen imidlertid ikke de menneskeretlige problemer. Eksemplet er muligvis ekstremt (krigen mod terror), men faren ved sådanne opdelinger mellem afgørelse og fuldbyrdelse må man generelt være opmærksom på. Drømmen om et fælles EU-retsrum må ikke udvikle sig til et mareridtsagtigt EU-retstomrum.

For det andet: Kvaliteten af EU's retsakter lader ofte en hel del tilbage at $\varnothing$ nske (jf. også Asp, 2004). De er udarbejdet på meget kort tid, ofte uden omfattende forarbejde og i et politisk klima, som gør endeløse kompromisser nødvendigt. Måske kan dette problem til en vis grad afhjælpes i forbindelse med den nationale implementering, men der er også en fare for, at den nationale implementering overtager uklarhederne. Når det drejer sig om materiel strafferet, forhindrer legalitetsprincippet til en vis grad, at uklarheder m.m. kommer borgeren til skade. Spørgsmålet er, om borge- 
ren på samme måde er beskyttet mod uklarheder vedrørende anerkendelse af udenlandske afgørelser om udlevering, beslaglæggelse, bevissikring osv.?

For det tredje: Det strafferetlige samarbejde, som det ser ud nu, rummer muligheder for at fungere relativt fornuftigt. Det er ikke princippet om gensidig anerkendelse, der som sådan skaber problemer, men problemerne kan opstå ved den måde, som reglerne gennemføres på. Vestergaard konkluderer vedrørende arrestordrens implementering i dansk ret, at "det må konstateres, at selve regelgrundlaget nu giver mulighed for fornuftige og forsvarlige afgørelser", og de aktører, som skal gennemføre ordningen, vil kunne bidrage til at sikre den enkeltes grundlæggende rettigheder (Vestergaard, 2004, s. 653). Det er imidlertid også et væsentligt spørgsmål, om reglerne åbner mulighed for uforsvarlige og ufornuftige afgørelser. Retsregler skal jo bl.a. sikre mod misbrug og misheld. Det er kernen i den nuværende udvikling: Vi har som danskere tillid til, at domstole og administrative myndigheder forvalter retten på "fornuftig måde", men vi har ingen garanti for, at andre landes domstole og administrative myndigheder har samme opfattelse af "fornuftig måde", og vi har ringe garanti for, at anvendelsen ikke påvirkes af politisk hede emner. Spørgsmålet er, om tilslutningen til Menneskerettighedskonventionen er nok.

\subsection{Afhjcelpning af problemerne - nogle foreløbige ideer}

Konsekvenserne af de nævnte problemerne kan i praksis afbødes ved at fastholde og udbygge følgende tre principper i EU-lovgivningen. For det første et ligestillingsprincip, der i videst mulige omfang lader fuldbyrdelseslandets lovgivning finde anvendelse på selve fuldbyrdelsen af afgørelsen. Det er et princip, som f.eks. fremgår af rammeafgørelsen om konfiskation og om gensidig anerkendelse af bødestraffe. Herved sikres i et vist omfang de retsgarantier, som fuldbyrdelseslandet normalt anvender i forbindelse med fuldbyrdelse af de pågældende typer af afgørelser. Det kan være garantier vedrørende gratis retshjælp, tolkebistand, selvinkriminering, regler for fremgangsmåden ved ransagning osv. Disse garantier vil finde anvendelse, selvom de er mere vidtgående end garantierne i det land, hvor afgørelsen stammer fra.

For det andet et territorieprincip, der tilsigter, at lovovertrædelser begået på et lands territorium, som udgangspunkt skal strafforfølges i dette land. I groft forenklet form kan det forklares som følger. En EU-borger, som rejser til et andet land og begår en forbrydelse, vil risikere ringere retsbeskyttelse, hvis dette andet land har ringere retsbeskyttelse. Den er den ulempe, man som borger må leve med, hvis man vil benytte sig af den fri bevægelighed. Men samtidigt - og det er fordelen - vil den borger, som begår en lovovertrædelse hjemme, have en vis sikkerhed for at blive strafforfulgt hjemme og opnå hjemlandets retsbeskyttelse. Herved undgår borgeren den belastning, som det er at blive strafforfulgt i et fremmed land. Samtidigt begrænses nogle af de problemer, som det fælles EU-retsrum kan accentuere. For at opnå den ønskede beskyttelse, må princippet dog kombineres med et ne bis in idem princip, så 
det fremmede land afskæres fra at strafforfølge, hvis forfølgning sker i hjemlandet. Herefter vil personer bosat i Holland ikke risikere strafforfølgning i Tyskland i forbindelse med hashsalg, der er foregået i Holland (jf. problemstillingen i dom afsagt af EF-domstolen i 2003, sag C-187/01). Ideen er naturligvis ikke uproblematisk. Det kan være svært at finde regler for, hvem der kan/skal strafforfølge, når en lovovertrædelse er begået på flere landes territorium (f.eks. smugling), og når den har virkning i flere lande. Ideelt set kræves således et fælles sæt jurisdiktionsregler. Men allerede nu lægges op til, at en variant af territorieprincippet skal finde anvendelse i bl.a. forslag til rammeafgørelse om fuldbyrdelse i EU af afgørelser om konfiskation.

For det tredje et processuelt legalitetsprincip, der sikrer, at kun ved relativt klar hjemmel til anerkendelse af fremmede afgørelser, skal der ske anerkendelse. Er det tvivlsomt, om betingelserne for anerkendelse er opfyldt - således som de fremgår af den nationale gennemførelseslov - så skal retshjælp/beslaglæggelse/konfiskation/udlevering m.m. afslås. EF-domstolen har fastslået, at legalitetsprincippet udelukker et strafansvar (eller et skærpet strafansvar), som alene baseres på en forordning eller et direktiv (se også Asp, 2004, og fra EF-domstolens retspraksis f.eks. sag 80/86). Der skal - ideelt set - være klar hjemmel i national lovgivning. Ved overførelse af det samme princip på strafferetligt samarbejde, kan nogle uheldige konsekvenser af øget strafferetligt samarbejde måske undgås.

\section{Sammenfatning og perspektiv}

De negative konsekvenser af EU's harmonisering af materiel strafferet synes fra et nordisk perspektiv relativt klare; repressionsniveauet $\emptyset$ ges ved ny- og opkriminaliseringer (se f.eks. Asp 2004, Elholm 2002, s. 77 ff., Lahti 2003, s. 441, Nuotio 2001, s. 303). De negative konsekvenser af det strafferetlige samarbejde vil efter omstændigheder kunne være en forringelse af individets retsbeskyttelse. Om det vil ske, kommer an på de konkrete retsakters indhold og måden, de forvaltes på i landene. Konsekvenserne af de rammeafgørelser, som er behandlet i denne artikel, er i så henseende ikke klarlagte, men der er næppe tale om drastiske forringelser af individets retsbeskyttelse. Principielt rummer det strafferetlige samarbejde gode muligheder for at sikre og ligefrem styrke retsgarantierne, og nordiske forskere har været fortalere for strafferetligt samarbejde, når blot individets retsstilling sikres (se Lahti 2003 med henvisninger).

Selvom retsbeskyttelsen sikres, er der måske alligevel et væsentligt problem forbundet med det strafferetlige samarbejde. Som nævnt ovenfor, kan strafferetligt samarbejde ikke ses som et alternativ til harmonisering af materiel strafferet (jf. også Asp 2004). For det første bygger EU-reglerne om strafferetligt samarbejde på og henviser til EU-reglerne vedrørende materiel strafferet (f.eks. vedrørende definitionen af terrorisme). For det andet er en vis harmonisering af materielle regler i nogle tilfælde nødvendigt for at skabe strafferetligt samarbejde, og det letter i hvert fald samarbejdet (jo 
mere ensartede regler, jo mere gnidningsløst samarbejde - må man formode). For det tredje er den politiske situation den, at der i EU arbejdes på såvel udbygget samarbejde, som harmonisering af materiel strafferet. Harmoniseringen tilstræbes som mål i sig selv, bl.a. som udtryk for graden af EU-integration. På samme måde er et fælles EU-retsrum også udtryk for graden af integration.

Samarbejde og harmonisering kan således i vidt omfang ses som to sider af samme sag, og spørgsmålet er, om den nære forbindelse er med til at skubbe udviklingen i samme retning? Strafferetligt samarbejde, herunder navnlig vidtgående anvendelse af princippet om gensidig anerkendelse, kan måske ligefrem $\emptyset$ ge behovet for harmonisering af den materielle strafferet. Man kan måske sågar forvente, at de alenlange positivlister i rammeafgørelserne vil fungere som katalog over emner, der skal harmoniseres i nærmeste fremtid? Faren er altså - set fra et nordisk perspektiv at jo mere vidtgående det strafferetlige samarbejde bliver, jo større pres for harmonisering af materiel strafferet og dermed $\emptyset$ get repressionsniveau.

\section{Litteratur:}

Petter Asp: "Mutual Recognition and the Development of Criminal Law Coo-peration" (conference paper Bergen 20.-21. February 2004), under trykning.

Iain Cameron: "Report to the Swedish Foreign Office on Legal Safeguards and Targeted Sanctions", Oct. 2002, Uppsala Universitet, offentliggjort elektronisk på http://wwwhotel.uu.se/juri/sii/index.html

Thomas Elholm: "Den europæiske Unions harmonisering af strafferetten", i NTfK, 2002, s. 77-105.

Vagn Greve: "European Criminal Policy. Towards Universal Laws?", i Nils Jareborg (red.): Towards Universal Law. Trends in National, European and International Lawmaking, Uppsala, 1995, s. 91-116.

Raimo Lahti: referat vedrørende "Straffrättsligt samarbete i EU:s tredje pelare - något att sträva efter?", i Förhandlingarna vid Det 36 nordiske juristmötet $i$ Helsingfors 15-17 augusti 2002, Del I, Jyväskylä, 2002, s. 431-444, offentliggjort elektronisk på http://www.congrex.fi/njm2002/referat

Kimmo Nuotio: "Straffrätten europeiseras", i NTfK, 2001, s. 289-308.

Per Ole Träskman: referat vedrørende "Straffrättsligt samarbete i EU:s tredje pelare - något att sträva efter?", i Förhandlingarna vid Det 36 nordiske juristmötet $i$ Helsingfors 15-17 augusti 2002, Del II, Jyväskylä, 2002, s. 462-470.

Jørn Vestergaard: "Udlevering til strafforfølgning m.v. - den europæiske arrestordre som udtryk for gensidig anerkendelse”, i Festskrift til Hans Gammeltoft-Hansen, København, 2004, s. 627-653.

Adresse:

Syddansk Universitet

Campusvej 55

DK-5230 Odense M

E-post: tel@sam.sdu.dk 